\title{
Removal of lead, mercury and nickel using the yeast Saccharomyces cerevisiae
}

\author{
Remoción de plomo, mercurio y níquel utilizando la levadura \\ Saccharomyces cerevisiae
}

\author{
Cherlys Infante J, ${ }^{1 *}$ M.Sc, Deniles De Arco R, ${ }^{1}$ M.Sc, Edgardo Angulo M, ${ }^{2}$ M.Sc.
}

\begin{abstract}
${ }^{1}$ Universidad de Cartagena, Faculty of Pharmaceutical Sciences, Pharmaceutical Chemistry Programme. Av del Consulado, Calle 30 Nro. 48-152 Cartagena, Colombia. ${ }^{2}$ Universidad del Atlantico, Faculty of Basic Sciences, Chemistry Programme. Dirección Km 7 Antigua vía Puerto Colombia, Barranquilla, Atlantico.*Correspondence: cinfantej@unicartagena.edu.co
\end{abstract}

Received: June 2013; Accepted: December 2013.

\begin{abstract}
Objective. In this study the biomass of the yeast Saccharomyces cerevisiae was used to remove lead, mercury and nickel in the form of ions dissolved in water. Materials and methods. Synthetic solutions were prepared containing the three heavy metals, which were put in contact with viable microorganisms at different conditions of $\mathrm{pH}$, temperature, aeration and agitation. Results. Both individual variables and the interaction effects influenced the biosorption process. Throughout the experimental framework it was observed that the biomass of Saccharomyces cerevisiae removed a higher percentage of lead ( $86.4 \%$ ) as compared to mercury and nickel (69.7 and $47.8 \%$ respectively). When the $\mathrm{pH}$ was set at a value of 5 the effect was positive for all three metals. Conclusions. $\mathrm{pH}$ was the variable that had a greater influence on the biosorption of lead on the biomass of Saccharomyces cerevisiae. The affinity of the heavy metals for the biomass followed the order $\mathrm{Pb}>\mathrm{Hg}>\mathrm{Ni}$.
\end{abstract}

Key words: Bioremediation, heavy metals, biomass, contaminant removal, bioaccumulation (Source: $D E C S$ ).

\section{RESUMEN}

Objetivo. En este estudio se utilizó la biomasa de la levadura Saccharomyces cerevisiae para retener plomo, mercurio y níquel en forma de iones disueltos en agua. Materiales y métodos. Se prepararon soluciones sintéticas que contenían los tres metales pesados, las cuales se pusieron en contacto con el microorganismo en forma viable a diferentes condiciones de $\mathrm{pH}$, temperatura, aireación y agitación. Resultados. Tanto las variables individuales como los efectos de interacción influyeron sobre el proceso de biosorción. A través de todos los experimentos, se observó que la biomasa de Saccharomyces cerevisiae eliminó un mayor porcentaje de plomo (86.4\%) en comparación al mercurio y al níquel (69.7 y $47.8 \%$ respectivamente). Cuando el pH se fijó en valor de 5 , el efecto fue positivo para los tres metales. Conclusiones. El pH fue la variable que tuvo una mayor influencia en la biosorción de plomo sobre la biomasa de Saccharomyces cerevisiae. La afinidad de los metales pesados por la biomasa siguió el orden $\mathrm{Pb}>\mathrm{Hg}>\mathrm{Ni}$.

Palabras clave: Biorremediación, metales pesados, biomasa, remoción de contaminantes, bioacumulación (Fuente: DECS). 


\section{INTRODUCTION}

Low concentrations of heavy metals can be highly toxic to microorganisms, whereas high concentrations can be tolerated if they are provided with enough sulfur. The toxicity of metals such as lead is well known; however, for others such as copper, zinc and nickel, their effects and permissible limits in surface waters are still under discussion (1).

Uptake mechanisms range from physical adsorption, ion exchange with the functional groups of the cell wall of the microorganism or they may penetrate into the cytoplasm and accumulate in the form of granules or intracellular inclusions (2).

Various microorganisms have been used for bioremediation purposes, such as bacteria, yeasts, fungi and microalgae; biosorbents based on macroalgae in non-viable state have also been prepared and have been effective in the removal of heavy metals from industrial effluents at concentrations ranging from 1 to $100 \mathrm{mg} / \mathrm{L}(2)$.

Growing cells may show a greater capacity for the removal of metals than non-viable biomass, especially in environments with enough nutrients ( 3 )

Sources of pollution may be natural such as the erosion and weathering of rocks; or anthropogenic erosion, manufacturing pigments, batteries, biocides, processing of ores and metals, industrial effluent from electroplating plants, effluents from tanneries and sanitary landfills (4).

Saccharomyces cerevisiae possesses phosphate, amino, carboxyl and hydroxyl groups in its cell wall, which are responsible for the removal of heavy metals (5).

The advantages of the use of Saccharomyces cerevisiae include the global boom in bioethanol production, which ensures the availability of a steady supply of residual biomass that could be used in the bioremediation of industrial effluents (6). Moreover, this yeast is considered as safe, which favors its use in practical applications that will thereafter be easily accepted by the population. S. cerevisiae has also been immobilized for recovering precious metals such as platinum (7), being considered as a cheap and plentiful source of biomass, making its application feasible in the

\section{INTRODUCCIÓN}

Las bajas concentraciones de metales pesados pueden ser altamente tóxicas para los microorganismos, mientras que altas concentraciones pueden ser toleradas si se provee suficiente sulfuro. Es bien conocida la toxicidad de metales como el plomo; sin embargo, para otros como el cobre, zinc y níquel, aún se discuten sus efectos y sus límites permisibles en aguas superficiales (1).

Los mecanismos de captación van desde adsorción física, intercambio iónico con los grupos funcionales de la pared celular del microorganismo o bien pueden penetrar al citoplasma y acumularse en forma de gránulos o inclusiones intracelulares (2).

Se han utilizado diversos microorganismos con fines de biorremediación, como bacterias, levaduras, hongos y microalgas; también se han preparado biosorbentes a base de macroalgas en estado no viable que han sido efectivas en la remoción de metales pesados de efluentes industriales en concentraciones que van desde 1 a $100 \mathrm{mg} / \mathrm{L}$ (2).

Las células en crecimiento pueden mostrar una mayor capacidad de remoción de metales que la biomasa no viable, especialmente en ambientes con suficientes nutrientes ( 3 )

Las fuentes de contaminación pueden ser naturales como la erosión y meteorización de rocas; o antrópicas como la erosión, fabricación de pigmentos, baterías, biocidas, procesamiento de menas y metales, efluentes de industrias de galvanoplastia, efluentes de curtiembres y de rellenos sanitarios (4).

Saccharomyces cerevisiae posee grupos fosfato, amino, carboxilo e hidroxilo en su pared celular, los cuales son responsables de la remoción de metales pesados (5).

Entre las ventajas del uso de Saccharomyces cerevisiae está el auge mundial en la producción de bioetanol, con lo cual se garantiza la disponibilidad de un suministro estable de biomasa residual que podría ser utilizada en la bioremediación de efluentes industriales (6). Además, esta levadura es considerada como segura, lo que favorece su uso en aplicaciones prácticas que luego serán fácilmente aceptadas por la población. S. cerevisiae también ha sido inmovilizada para recuperar metales preciosos como el platino (7), siendo considerada como una fuente barata y abundante de biomasa, lo que hace factible su aplicación en la descontaminación de efluentes de la industria minera. 
decontamination of effluents from the mining industry.

The brewing industry is another important source of low-cost yeast with flocculating properties, which facilitates the mechanical separation at the end of the biosorption process ( 8$)$.

On the other hand, environmental conditions such as aeration, agitation, temperature and $\mathrm{pH}$ influence cell growth and an effect on the uptake of heavy metals associated with both the microorganism and the fluid dynamics of the medium could therefore be expected.

The adsorption of heavy metals in the biomass of $S$. cerevisiae has been reported in numerous studies (6-11).

Based on the above, experiments were carried out in order to determine the influence of the variables $\mathrm{pH}$, temperature, agitation and aeration on the biosorption of lead, mercury and nickel in the biomass of $S$. cerevisiae.

\section{MATERIALS AND METHODS}

Microorganism. Commercial dry active baker's yeast was used, which was kept in refrigeration at $4^{\circ} \mathrm{C}$.

Culture medium. A culture medium containing $20 \mathrm{~g} / \mathrm{L}$ of glucose, $20 \mathrm{~g} / \mathrm{L}$ of peptone and $10 \mathrm{~g} / \mathrm{L}$ of yeast extract was prepared for the cultures per lot of S. cerevisiae.

This medium was dosed with lead nitrate, nickel chloride and mercuric chloride solutions to obtain a concentration of $100 \mu \mathrm{M}$ in each of the heavy metals, using a workload of $100 \mathrm{~mL}$ in each experiment.

Biosorption. Biosorption tests were carried out according to a $2^{4}$ factorial design in which the levels of each factor were identified according to the coding (Table 1 ).

The tests were conducted by inoculating the medium with $0.2 \mathrm{~g}$ of dry yeast and incubated

Table 1. Levels of variables.

\begin{tabular}{ccc}
\hline Variables & High level & Low level \\
\hline $\mathrm{A}=\mathrm{pH}$ & 5 & 3.5 \\
$\mathrm{~B}=$ Temperature & $30^{\circ} \mathrm{C}$ & $25^{\circ} \mathrm{C}$ \\
$\mathrm{C}=$ Agitation & $150 \mathrm{rpm}$ & $100 \mathrm{rpm}$ \\
$\mathrm{D}=$ Aeration & $4 \mathrm{vvm}$ & $1 \mathrm{vvm}$ \\
\hline
\end{tabular}

La industria cervecera es otra fuente importante de levadura de bajo costo con propiedades floculantes, lo cual facilita la separación mecánica al final del proceso de biosorción (8).

Por otro lado, las condiciones ambientales como la aireación, agitación, la temperatura $\mathrm{y}$ el $\mathrm{pH}$ influyen sobre el crecimiento celular y podría esperarse por tanto un efecto sobre la captación de metales pesados asociado tanto al microorganismo como a la fluidodinámica del medio.

La adsorción de metales pesados en la biomasa de $S$. cerevisiae ha sido reportada en numerosos estudios (6-11).

Con base en lo anterior se realizaron experiencias con el fin de determinar la influencia de las variables $\mathrm{pH}$, temperatura, agitación y aireación sobre la biosorción de Plomo, Mercurio y Níquel en la biomasa de $S$. cerevisiae.

\section{MATERIALES Y MÉTODOS}

Microorganismo. Se utilizó levadura de panadería seca activa comercial, la cual fue mantenida en refrigeración a $4^{\circ} \mathrm{C}$.

Medio de cultivo. Se preparó un medio de cultivo que contenía $20 \mathrm{~g} / \mathrm{L}$ de glucosa, $20 \mathrm{~g} / \mathrm{L}$ de peptona y $10 \mathrm{~g} / \mathrm{L}$ de extracto de levadura para los cultivos por lote de $S$. cerevisiae.

Este medio se dosificó con soluciones de nitrato de plomo, cloruro de níquel y cloruro de mercurio para obtener una concentración de $100 \mu \mathrm{M}$ en cada uno de los metales pesados, utilizando un volumen de trabajo de $100 \mathrm{~mL}$ en cada experiencia.

Biosorción. Los ensayos de biosorción se realizaron de acuerdo a un diseño con arreglo factorial $2^{4}$ en el cual los niveles de cada factor fueron identificadas según codificación (Tabla 1).

Los ensayos se realizaron inoculando el medio con $0.2 \mathrm{~g}$ de levadura seca e incubando por 24 horas, para luego separar las fases mediante filtración con papel de $0.45 \mu \mathrm{m}$.

Determinación de metales pesados. EI método de espectroscopia de absorción atómica, fue el seleccionado para analizar los metales pesados, utilizando el espectrofotómetro UNICAM 969. Todas las muestras fueron analizadas por triplicado. 
for 24 hours, to then separate the phases by filtration with a $0.45 \mu \mathrm{m}$ paper.

Determination of heavy metals. The atomic absorption spectroscopy method was selected to analyze the heavy metals, using the spectrophotometer UNICAM 969. All samples were analyzed in triplicate.

The lead and nickel were determined using the flame atomization technique, while the cold vapor technique was used for analyzing mercury, on the basis of the standardized methods compiled in the APHA in section 3112B (12).

Experiment design. A complete $2^{4}$ factorial design was used. The experiments planned through the combination of the variables under study were performed randomly and in duplicate.

The removal percentages for each metal were reported as the mean of the experiments \pm the standard deviation of the mean effect, calculated from the effects of third and fourth order interactions.

The software SPSS Statistics version 17.0 was used for the calculation of the effects. The effects calculated were compared with a reference distribution (F test) at a confidence level of $95 \%$.

\section{RESULTS}

The biomass of $S$. cerevisiae adsorbed the metals under study in different proportions (Table 2), showing greater affinity for lead and lower affinity for nickel.

Table 2. Removal percentages of $\mathrm{Pb}, \mathrm{Hg}$ and $\mathrm{Ni}$ by $\mathrm{S}$. cerevisiae.

\begin{tabular}{cccc}
\hline Treatment & Pb \% removed & Hg \% removed & Ni \% removed \\
\hline I & 73.7 & 50.8 & 35.3 \\
A & 100 & 61.5 & 41.4 \\
B & 48.4 & 91.3 & 72.4 \\
Ab & 100 & 85.3 & 68.9 \\
C & 93.7 & 58.9 & 38.8 \\
Ac & 66.4 & 74.0 & 58.2 \\
Bc & 71.2 & 51.8 & 31.0 \\
Abc & 100 & 85.8 & 57.9 \\
D & 76.7 & 52.9 & 29.5 \\
Ad & 100 & 56.0 & 38.0 \\
Bd & 83.8 & 74.3 & 48.2 \\
Abd & 100 & 75.8 & 65.5 \\
Cd & 77.6 & 91.3 & 58.6 \\
Acd & 100 & 74.6 & 46.2 \\
Bcd & 91.8 & 54.7 & 33.4 \\
Abcd & 100 & 75.8 & 41.5 \\
\hline
\end{tabular}

La determinación de plomo y níquel se realizó utilizando la técnica de atomización con llama, mientras que para analizar el mercurio, se utilizó la técnica de vapor frio, tomando como base los métodos normalizados recopilados en el APHA en la sección 3112B (12).

Diseño experimental. Se utilizó un diseño con arreglo factorial completo $2^{4}$. Los experimentos planeados mediante la combinación de las variables bajo estudio fueron realizados en orden aleatorio y por duplicado.

Los porcentajes de remoción para cada metal se reportaron como la media de los experimentos \pm la desviación estándar del efecto medio, calculada a partir de los efectos de las interacciones de tercer y cuarto orden.

Para el cálculo de los efectos se utilizó el software SPSS Statistics versión 17.0. Los efectos calculados fueron comparados con una distribución de referencia (prueba F) a un nivel de confianza de $95 \%$.

\section{RESULTADOS}

La biomasa de $S$. cerevisiae adsorbió los metales bajo estudio en distintas proporciones (Tabla 2), mostrando una mayor afinidad por el plomo y una menor afinidad por el níquel.

El promedio de eliminación para el plomo fue $86.4 \pm 3.8 \%$, para el mercurio $69.7 \pm 3.66 \%$ y para el níquel $47.8 \pm 2.67 \%$. La capacidad media de biosorción para el plomo fue $8.9 \mathrm{mg} / \mathrm{g}$ de levadura seca. El único metal para el cual se obtuvo un $100 \%$ de eliminación fue el plomo, particularmente en los experimentos a $\mathrm{pH} 5$, exceptuando el ensayo donde la agitación y el $\mathrm{pH}$ estuvieron en el nivel alto.

La biomasa de $S$. cerevisiae presentó una capacidad media para el mercurio de $10.25 \mathrm{mg} / \mathrm{g}$. La capacidad de adsorción para el níquel fue 2.8 $\mathrm{mg} / \mathrm{g}$ de levadura seca.

Se observó una influencia significativa de las variables para cada metal, representada por efectos simples e interacciones de segundo y tercer orden (Tabla 3). Los efectos calculados corresponden a los coeficientes del modelo lineal, los cuales se consideraron significativos cuando el valor de probabilidad fue menor de $0.05(p \leq 0.05)$.

Análisis de los efectos sobre la biosorción del plomo. De los seis efectos significativos para este metal, el $\mathrm{pH}$ fue la variable que tuvo 
For average removed for lead was $86.4 \pm 3.8$, for

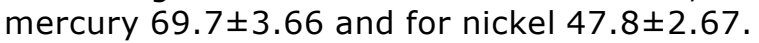
The average biosorption capacity for lead was $8.9 \mathrm{mg} / \mathrm{g}$ of dry yeast. The only metal for which a removal of $100 \%$ was obtained was lead, particularly in experiments with a $\mathrm{pH}$ of 5 , except the trial where the agitation and $\mathrm{pH}$ were at a high level.

The biomass of $S$. cerevisiae showed an average capacity for mercury of $10.25 \mathrm{mg} / \mathrm{g}$. The adsorption capacity for nickel was 2.8 $\mathrm{mg} / \mathrm{g}$ of dry yeast.

A significant influence was observed in the variables for each metal, represented by simple effects and second and third order interactions (Table 3 ). The effects calculated correspond to the coefficients of the linear model, which were considered significant when the likelihood value was less than $0.05(p \leq 0.05)$.

Table 3. Effects of the variables on the biosorption of lead, mercury and nickel.

\begin{tabular}{cccc}
\hline Treatment & $\mathbf{P b}$ & $\mathbf{H g}$ & $\mathbf{N i}$ \\
\hline I & 86.4 & 69.7 & 47.8 \\
A & 18.7 & 7.8 & 8.8 \\
B & 0.9 & 9.3 & 9.1 \\
Ab & 7.5 & 4.8 & 3.4 \\
C & 2.2 & 2.4 & -4.2 \\
Ac & -10.6 & 5.5 & 1.7 \\
Bc & 5.4 & -17 & -18.6 \\
Abc & 2.9 & 9.4 & 3.6 \\
D & 9.6 & -0.5 & -5.4 \\
Ad & -1.1 & -5.6 & -3.4 \\
Bd & 4.4 & -7.9 & -5.0 \\
Abd & -12.8 & 4.2 & 3.9 \\
Cd & -0.025 & 7.0 & 3.8 \\
Acd & 8.4 & -5.6 & -9.2 \\
Bcd & -3.6 & -2.1 & -0.4 \\
Abcd & -4.7 & 0.5 & -0.6 \\
\hline
\end{tabular}

Analysis of the effects on the biosorption of lead. Of the six significant effects for this metal, the $\mathrm{pH}$ was the variable that had the greatest influence on the uptake of lead by the biomass (Figure 1).

The second most significant and favorable effect for the retention of lead was aeration, this result indicates that the viable state and oxidative metabolism of yeast influence positively on the uptake of this metal. The interaction between $\mathrm{pH}$ and agitation had $\mathrm{a}$ negative effect on biosorption.

In terms of third-order interactions, a favorable effect was observed for the interaction

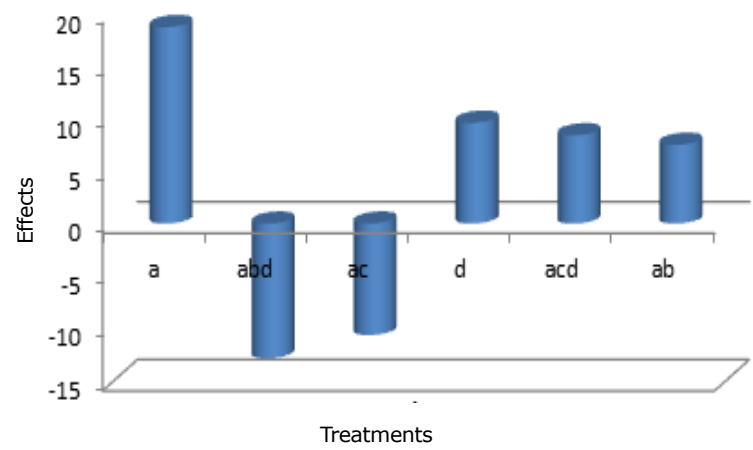

Figure 1. Comparison of the significant effects on the biosorption of lead.

más influencia en la captación de plomo por la biomasa (Figura 1).

El segundo efecto más significativo y favorable para la retención del plomo fue la aireación, este resultado indica que el estado viable y el metabolismo oxidativo de la levadura influyen de manera positiva en la captación de este metal. La interacción entre el pH y la agitación tuvo efecto negativo sobre la biosorción.

En cuanto a las interacciones de tercer orden, se presentó un efecto favorable para la interacción entre el pH, la agitación y la aireación, lo que indica que si el proceso de biosorción es agitado mecánicamente a $\mathrm{pH} 5$, también deberá airearse con el fin de generar esta interacción positiva; mientras que la interacción entre el $\mathrm{pH}$, la temperatura y la aireación fue negativa, estableciendo a la temperatura como una variable crítica en este proceso.

Análisis de los efectos sobre la biosorción del mercurio. Como se observa en la figura 2, la mayoría de los efectos resultaron significativos para la biosorción de mercurio: la temperatura, el $\mathrm{pH}$, todas las interacciones de segundo orden excepto la que ocurrió entre el pH y la temperatura; así como las interacciones de tercer orden entre $\mathrm{pH}$, temperatura y agitación y entre $\mathrm{pH}$, agitación y aireación.

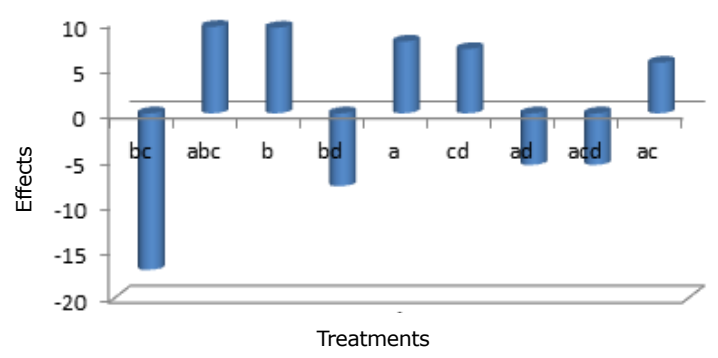

Figure 2. Comparison of the significant effects on the biosorption of Mercury. 
between $\mathrm{pH}$, agitation and aeration, which indicates that if the biosorption process is mechanically agitated at a $\mathrm{pH}$ of 5 , it also must be aerated in order to generate this positive interaction; while the interaction between $\mathrm{pH}$, temperature and aeration was negative, setting the temperature as a critical variable in this process.

\section{Analysis of the effects on the biosorption of mercury. As shown in Figure 2, most of the effects were significant for mercury biosorption: temperature, $\mathrm{pH}$, all second-order interactions except for that between $\mathrm{pH}$ and temperature; as well as third-order interactions between $\mathrm{pH}$, temperature and agitation and between $\mathrm{pH}$, agitation and aeration.}

In addition, a greater number of positive rather than negative effects was noted. The temperature and $\mathrm{pH}$ had positive effects as well as the interactions between $\mathrm{pH}$ and agitation as well as between agitation and aeration.

The interactions between temperature and agitation; temperature and aeration; as well as $\mathrm{pH}$ and aeration, showed a negative effect, the first being the stronger, indicating that the desorption of mercury is favored under these conditions.

The third-order interaction between $\mathrm{pH}$, temperature and agitation was positive and had a strong effect comparable to the effects of $\mathrm{pH}$ and temperature separately on the uptake of mercury; while the interaction between $\mathrm{pH}$, agitation and aeration had negative effect.

Analysis of the effects on the biosorption of nickel. Figure 3 shows that the biosorption of nickel displayed the highest number of negative effects, which is consistent with the lower removal percentage observed in this study.

All the variables under study influenced on the biosorption of nickel individually, temperature and $\mathrm{pH}$ with positive effects and agitation and aeration with negative effects but with a lower weight than the first two.

The most significant effect was the second-order interaction between temperature and agitation; it can be noticed that as in the case of mercury biosorption, it was negative and had a higher magnitude than the rest of the effects.

It is observed that the third-order interactions, which were significant for the biosorption of lead, were also significant in the case of nickel, but with the opposite sign.
Además, se observó un mayor número de efectos positivos que negativos. La temperatura y el $\mathrm{pH}$ tuvieron efectos positivos al igual que las interacciones entre el $\mathrm{pH}$ y la agitación así como entre la agitación y la aireación.

Las interacciones entre la temperatura y la agitación; temperatura y aireación; así como $\mathrm{pH}$ y aireación, tuvieron un efecto negativo, siendo la primera la más fuerte, indicando que bajo estas condiciones se favorece la desorción del mercurio.

La interacción de tercer orden entre el $\mathrm{pH}$, la temperatura y la agitación fue positiva y tuvo un efecto fuerte comparable a los efectos del $\mathrm{pH}$ y de la temperatura por separado sobre la captación de mercurio; mientras que la interacción entre el pH, la agitación y la aireación tuvo efecto negativo.

Análisis de los efectos sobre la biosorción de níquel. La figura 3 muestra que la biosorción de níquel presentó el mayor número de efectos negativos, lo cual es coherente con el menor porcentaje de remoción observado en este estudio.

Todas las variables estudiadas influyeron sobre la biosorción de níquel de forma individual, la temperatura y el $\mathrm{pH}$ con efectos positivos y la agitación y la aireación con efectos negativos pero de menor peso que las dos primeras.

El efecto más significativo fue la interacción de segundo orden entre la temperatura y la agitación; puede notarse que al igual que para el caso de la biosorción de mercurio, este fue negativo y de mayor magnitud que el resto de los efectos.

Se observa que las interacciones de tercer orden que fueron significativas para la biosorción de plomo también fueron significativas para el caso del níquel pero con signo contrario.

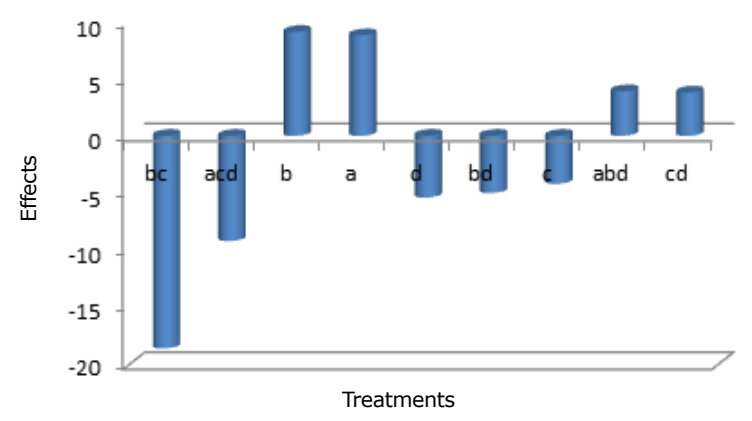

Figure 3. Comparison of the significant effects on the biosorption of Nickel. 


\section{DISCUSSION}

The higher affinity of biomass for lead was a result in line with what has been reported in other studies $(13,14)$.

At a $\mathrm{pH}$ of 5 , lead is a positive divalent ion that can interact with the negative functional groups of the cell wall of yeast (13).

Zhang et al (15) found an adsorption capacity of $6.52 \mathrm{~Pb} / \mathrm{g} \mathrm{mg}$ of dry yeast, lower to that obtained in this study ( $8.9 \mathrm{mg} \mathrm{Pb} / \mathrm{g}$ of dry yeast). Skountzou et al (16) reported a capacity of $4 \mathrm{mg}$ $\mathrm{Pb} / \mathrm{g}$ based on a concentration of $20 \mathrm{mg} / \mathrm{L}$, as that used in this study; in addition, these authors obtained a removal percentage for lead of $71.8 \%$, lower to that obtained in this study.

Galedar and Younesi (17) reported a capacity of $1.2 \mathrm{mg} \mathrm{Ni} / \mathrm{g}$ of dry yeast in experiments with $S$. cerevisiae immobilized at a $\mathrm{pH}$ of 8 . Again, this capability was less than that obtained in this study. Another study found a removal rate for nickel of $72 \%$ from synthetic solutions, higher than that obtained in this study (18).

Suazo et al (19) found a direct relationship between the uptake of nickel and $\mathrm{pH}$ using $S$. cerevisiae var ellipsoideus; at a $\mathrm{pH}$ of 3.5 , the adsorption capacity was $5.74 \mathrm{mg} \mathrm{Ni} / \mathrm{g}$ of dry yeast for an initial concentration of $1000 \mu \mathrm{M}$. In this study, the capacity was approximately half of this value with an initial concentration ten times lower.

The repulsion between $\mathrm{H}^{+}$ions and metal ions at a low $\mathrm{pH}$ restricts access to ligands, but as the $\mathrm{pH}$ increases, more negatively charged ligands are exposed to capture heavy metals (13).

The effect of aeration can be explained taking into account that biosorption is performed with cells in a viable state with an aerobic metabolism, it is expected that a good air supply is reflected in a specific high growth rate and a better use of the nutrients in the culture medium.

The effect of agitation is related to the shear forces generated that could cause the desorption of the metal joined by weak bonds such as electrostatic attraction, hydrogen bonding and Van der Waals forces.

The positive effect of temperature for mercury and nickel can be attributed to an increase in ionic mobility. The relationship between the metal removal capacity and temperature was studied by Zhang et al (15) finding that the maximum

\section{DISCUSIÓN}

La mayor afinidad de la biomasa por el plomo, fue un resultado coherente con lo reportado en otros estudios $(13,14)$.

A pH 5, el plomo es un ión positivo divalente que puede interactuar con los grupos funcionales negativos de la pared celular de la levadura (13). Zhang et al (15) encontraron una capacidad de adsorción de $6.52 \mathrm{mg} \mathrm{Pb} / \mathrm{g}$ de levadura seca, menor a la obtenida en este estudio $(8.9 \mathrm{mg} \mathrm{Pb} / \mathrm{g}$ de levadura seca). Skountzou et al (16) reportaron una capacidad de $4 \mathrm{mg} \mathrm{Pb} / \mathrm{g}$ partiendo de una concentración de $20 \mathrm{mg} / \mathrm{L}$, igual a la utilizada en este estudio; además, estos autores obtuvieron un porcentaje de remoción para plomo de $71.8 \%$, inferior al obtenido en este estudio.

Galedar y Younesi (17) reportaron una capacidad de $1.2 \mathrm{mg}$ de $\mathrm{Ni} / \mathrm{g}$ de levadura seca, en experimentos con S. cerevisiae inmovilizada a pH 8. Nuevamente, esta capacidad fue inferior a la obtenida en este estudio. Otro estudio encontró un porcentaje de remoción de níquel, a partir de soluciones sintéticas, de $72 \%$, superior al obtenido en este estudio (18).

Suazo et al (19) encontraron una relación directa entre la captación de níquel y el pH utilizando $S$. cerevisiae var ellipsoideus; a pH 3.5, la capacidad de adsorción fue $5.74 \mathrm{mg} \mathrm{Ni} / \mathrm{g}$ de levadura seca para una concentración inicial de $1000 \mu \mathrm{M}$. En este estudio, la capacidad fue aproximadamente la mitad de este valor con una concentración inicial diez veces menor.

La repulsión entre los iones $\mathrm{H}^{+}$y los iones metálicos a pH bajo, restringe el acceso a los ligandos, pero a medida que aumenta el $\mathrm{pH}$, más ligandos con carga negativa quedan expuestos para captar metales pesados (13).

El efecto de la aireación puede explicarse teniendo en cuenta que la biosorción se realiza con células en estado viable con metabolismo aeróbico, es de esperar que un buen suministro de aire se refleje en una velocidad específica de crecimiento alta y un mejor aprovechamiento de los nutrientes del medio de cultivo.

El efecto de la agitación está relacionado con las fuerzas de cizalla generadas que podrían provocar la desorción del metal unido por enlaces de naturaleza débil como la atracción electrostática, los puentes de hidrógeno y las fuerzas de Van der Waals.

El efecto positivo de la temperatura para mercurio y níquel puede atribuirse a un aumento de la movilidad iónica. La relación entre la capacidad de 
capacity was obtained at $30^{\circ} \mathrm{C}(20)$, which corresponds to the high level used in this study.

In conclusion, the $\mathrm{pH}$ was the variable that had the greatest influence on the biosorption of lead, mercury and nickel on the biomass of $S$. cerevisiae. The temperature was the variable that most influenced the biosorption of mercury and nickel. Lead was the metal with greater affinity for biomass, followed by mercury and nickel, which can be asserted by comparing their removal percentage and the effects of the interaction of temperature and agitation. Second and third order interactions were significant for the biosorption of lead, mercury and nickel. Aeration only had a positive effect on the biosorption of lead, which can indicate a relationship between the uptake of lead and the metabolic state of the cell. The strongest negative effect on the biosorption of mercury and nickel was represented by the interaction between temperature and agitation.

\section{Acknowledgements}

The authors would like to thank the Universidad de Cartagena for its support in the conduction of this study. remoción de metales y la temperatura fue estudiada por Zhang et al (15) encontrando que la capacidad máxima se obtuvo a $30^{\circ} \mathrm{C}(20)$, la cual corresponde al nivel alto utilizado en este trabajo.

En conclusión, el $\mathrm{pH}$ fue la variable que tuvo una mayor influencia en la biosorción de plomo, mercurio y níquel sobre la biomasa de $S$. cerevisiae. La temperatura fue la variable que más influyó sobre la biosorción de mercurio y níquel. El plomo fue el metal con mayor afinidad por la biomasa, seguido por el mercurio y el níquel, lo cual puede afirmarse al comparar su porcentaje de remoción y los efectos de interacción de agitación y temperatura. Las interacciones de segundo y tercer orden fueron significativas para la biosorción de plomo, mercurio y níquel. La aireación sólo tuvo efecto positivo sobre la biosorción del plomo, lo cual puede indicar una relación entre la captación de plomo y el estado metabólico de la célula. El efecto negativo más fuerte sobre la biosorción del mercurio y el níquel estuvo representado por la interacción entre la temperatura y la agitación.

\section{Agradecimientos}

Los autores agradecen a la Universidad de Cartagena por su apoyo para la realización de este trabajo.

\section{REFERENCES}

1. Volesky B. Biosorption and me. Water Res 2007; 41:4017-4029.

2. Wang J, Chen C. Biosorbents for heavy metals removal and their future. Biotechnol Adv 2009; 27:195-226.

3. Li C, Xu Y, Jiang W, Dong $X$, Wang $D$, Liu B. Effect of $\mathrm{NaCl}$ on the heavy metal tolerance and bioaccumulation of Zygosaccharomyces rouxii and Saccharomyces cerevisiae. Biores Technol 2013; 143:46-52.

4. Soares E, Soares H. Bioremediation of industrial effluents containing heavy metals using brewing cells of Saccharomyces cerevisiae as a green technology: A review. Env Sci Pollut Res 2012; 19:1066-1083.

5. Gohari M, Hosseini S,Sharifnia S, Khatami M. Enhancement of metal ion adsorption capacity of Saccharomyces cerevisiae's cells by using disruption method. J Taiwan Inst Chem E 2013; 44:637-645.
6. Wang J, Chen C. Biosorption of heavy metals by Saccharomyces cerevisiae: A review. Biotechnol Adv 2006; 24:427-451.

7. Mack CL, Wilhelmi B, Duncan JR, Burgess JE.Biosorptive recovery of platinum from platinum group metal refining wastewaters by immobilised Saccharomyces cerevisiae. Water Sci Technol 2011; (63):149-55.

8. Soares E, Soares H. Cleanup of industrial effluents containing heavy metals: a new opportunity of valorising the biomass produced by brewing industry. Appl Microbiol Biotechnol 2013; 97(15):6667-6675.

9. Ruta L, Paraschivescu C, Matache M, Avramescu S, Farcasanu I C. Removing heavy metals from synthetic effluents using "kamikaze" Saccharomyces cerevisiae cells. Appl Microbiol Biotechnol 2010; 85:763-771. 
10. Li T, Liu Y, Peng Q, Hu X, Liao T, Wang H, Lu M. Removal of lead(II) from aqueous solution with ethylenediamine-modified yeast biomass coated with magnetic chitosan microparticles: Kinetic and equilibrium modeling. Chem Eng J 2013; 214:189-197.

11. Ramírez M, Pereira M, Ferreira S, Vasco O, Ocampo C. Packed bed redistribution system for $\mathrm{Cr}$ (III) and $\mathrm{Cr}(\mathrm{VI})$ biosorption by Saccharomyces cerevisiae. J Taiwan Inst Chem E 2012; 43: 428-432.

12. APHA. Métodos normalizados para el análisis de aguas potables y residuales. Método 3112 B. 3-23, 3-24. 21a Edición. España. Editorial Díaz de Santos; 2005.

13. Özer A, Özer D. Comparative study of the biosorption of $\mathrm{Pb}(\mathrm{II}), \mathrm{Ni}(\mathrm{II})$ and $\mathrm{Cr}(\mathrm{VI})$ ions onto $S$. cerevisiae: determination of biosorption heats. J Hazard Mater 2003; B100:219-229.

14. Chen C, Wang J. Influence of metal ionic characteristics on their biosorption capacity by Saccharomyces cerevisiae. Appl Microbiol Biotechnol 2007; 74:911-917.

15. Zhang $Y$, Fan C, Meng Q, Diao Z, Dong $L$, Peng $X$ et al. Biosorption of $\mathrm{Pb} 2+$ by Saccharomyces Cerevisiae in Staticand Dynamic Adsorption Tests. Bull Environ Contam Toxicol 2009; 83:708-712.
16. Skountzou $P$, Soupioni $M$, Bekatorou $A$, Kanellaki M, Koutinas A, Marchant $R$ et al. Lead(II) uptake during baker's yeast production by aerobic fermentation of molasses. Process Biochem 2003; 38:14791482.

17. Galedar M, Younesi H. Biosorption of ternary cadmium, nickel and cobalt ions from aqueous solution onto saccharomyces cerevisiae cells: batch and column studies. Am J Biochem Biotechnol 2013; 9(1):47-60.

18. Machado M, Soares E, Soares H. Removal of heavy metals using a brewer's yeast strain of Saccharomyces cerevisiae: chemical speciation as a tool in the prediction and improving of treatment efficiency of real electroplating effluents. J Hazard Mater $2010 ; 180(1-3): 347-53$.

19. Suazo E, Morales L, Cristiani M, Cristiani E. Efecto del $\mathrm{pH}$ sobre la biosorción de níquel (II) por Saccharomyces cerevisiae var. ellipsoideus. Rev CENIC Cienc Quim 2010; 41:1-12.

20. Zhang $Y$, Liu $W$, Zhang $L$, wang $M$, Zhao $M$. Application of bifunctional Saccharomyces cerevisiae to remove lead(II) and cadmium(II) in aqueous solution. Appl Surf Sci 2011; 257:9809-9816. 